\title{
Governmental Leadership without a Political Party
}

\author{
Raffaele De Mucci \\ Department of Political Sciences, Laps-Luiss Guido Carli Viale Romania, Rome, Italy \\ Email: rdemucci@luiss.it
}

How to cite this paper: De Mucci, R (2018). Governmental Leadership without a Political Party. Open Journal of Political Science, 8, 278-290.

https://doi.org/10.4236/ojps.2018.83020

Received: June 26, 2018

Accepted: July 22, 2018

Published: July 25, 2018

Copyright (C) 2018 by author and Scientific Research Publishing Inc. This work is licensed under the Creative Commons Attribution International License (CC BY 4.0).

http://creativecommons.org/licenses/by/4.0/

\begin{abstract}
This article focuses on the theme of strengthening government leadership within contemporary democracy schemes, irrespective of their forms of Government-parliamentary or presidential. They are, in most cases, leaders-without-party in the sense that, though (formally) sponsored by a political party, they manage to impose and legitimize themselves by virtue of their personalities along with a team of loyal followers, doing without their own party and often opposing to it. This phenomenon of "leadership concentration" of the head of Government is evident even in parliamentary systems where-according with the Germany's historical prototype-is defined as a "chancellor democracy". We can get many examples of this tendency around the world in the latest ten years. The Italian political experience of the last thirty years is assumed as an interesting case study, demonstrating the vitality and at same time the hidden risks of that process which enhances the personalistic model of "leader-without-party". All within the framework of a weak and partial democracy that is defined in various ways: hybrid, dissociative, personalized-prodromal signs of a possible step back towards a "populistic style".
\end{abstract}

\section{Keywords}

Chancellor Democracy, Personalized Leadership, Populism

\section{Introduction}

In this paper are advanced some findings of a broader search on which I'm working about the changes of Western democracy, understood as systems of Liberal representative democracies. These are increasingly corrupting in the sense that within the political system the Executive power strengthens its position in relation to the Parliament, while there is a clear process of personaliza- 
tion of the political leadership and on the other hand there are confusing suggestions of direct and "rethorical democracy" [Tulis, 1987: p. 39].

The first paragraph introduced the arrival point of this process in what we have decided to name "chancellor democracy" [Morlino, 2010: p. 221-222], which refers to the figure of the German Prime Minister and the position which came to assume, after the tragedy of Nazism, inside the institutional arrangements of contemporary Germany: a position of absolute pre-eminence in inter institutional relations, and especially free from party affiliation.

In the second paragraph three experiences are told that have a lot to do with the topic we are dealing with. These experiences correspond to three electoral events. In the order in which they happened: 1) UK, Spring 2006: the Brexit option wins the referendum: 2) USA, Autumn 2016: Donald Trump is elected President; 3) France, 2008: the outsider Macron asserts himself in the presidential elections with an unprecedent personal party, En March.

In the third part of the paper we assume as a specific case study, the fallout of this transformation process on the events of Italian politics, starting with the Berlusconi governments from the mid-90s up to the first decade of this century, and ending with the leadership assumed by Renzi in a government now freed from the control of the parties.

To conclude with the question of whether this process of personalizing government leadership can lead to populist and anti-democratic derives.

\section{From the Parliamentary Democracy to a "Chancellor Democracy"}

A long time has passed, and Western democracy has come a long way since Fabbrini, in an article in 1991, conceptualized the leader-party government as an alternative to the more usual schemes for cataloguing the strategies of government actions, namely the model of the party government and alternatively the model of the leader's government: the first typical of the parliamentary democracies that Lijphart would define "consociational" [Lijphart, 2001], the second of the presidential democracies (USA) or semi-presidential (France). However, both stem from a common historical root of British parliamentarianism, in which there was an absolute coincidence between the leader of the winning party in the elections and the premier of the government (in Lijphart's definition, this is the Westminster Model) [Fabbrini, 1991].

Apart from the case of Germany, where the Westminster effect manifested itself for a long time and acted in the direction of an almost automatic overlap between the leader of the majority party and Chancellor (Head of Government), through the systemic dynamics of effective bipartisanship within a system of proportional caliber, and apart from the case of Israel, which with the ephemeral reform of 1993 (immediately abrogated three years later), with which it was decided to proceed with the direct election of the Head of Government at the same time as the proportional election of the Knesset (the Lower House), also in Italy-almost simultaneously, after the 1994 elections-the conviction had been 
consolidated that the Prime Minister should be appointed by the President of the Republic, as prescribed by the Constitution, but this event turned into a kind of due act, as the Head of State could only indicate the leader appointed by the party that had won, albeit with a relative majority, the general elections (and not, as was previously the case in the so-called "first republic", the person he considered most reliable and capable of forming a coalition of majority and government as cohesive and stable as possible).

These are just a few examples of the transformation of the systems of parliamentary democracy with an associative-consensual structure [Lijphart, 2001] into what are defined as "chancellor democracy", with only an indicative reference to Germany, which, moreover, almost suffered this same characteristic in the post-war years, at least with reference to the bipartisan pillar that has given space and life, with increasing frequency, to coalitions of governments (centred around the coalition potential of the Liberals of the FPD) and even to the now repeated re-editions of Grosse Koalition between CDU and SPDE [Mommsen, 2007]. Merkel's leadership, increasingly free from the control of the Christian Democratic Party (CDU), is an effective demonstration of this transformation.

Merkel has been the head of the government in Germany since 2005 without interruptions with government formulas and alliances of every kind and political colour. Hesledership quite divided from political parties (her party, the CDU, would never have won the election without her candidacy to the premier) confirms the perfect adherence and consistency of what we call, not by chance, "chancellor democracy" [Helms, 2011].

That other authors apply to different European democratic systems, especially those of the "latest generation". In this sense, the case of Hungary is very popular, as it seemed to have adopted in 1989, after the Communist dictatorship, a scheme of parliamentary democracy similar in many ways to the German model and, like this one, slipping towards the strengthening of the role of the premier and of the executive power.

The President of the Republic, elected by the Assembly, has more in common with a constitutional monarch than with a politically active role; he has an influence on the Head of Government, in the sense that he is responsible for the appointment shared with that of the Parliament (formally he can only address a recommendation that the Assembly must decide by majority whether to accept or not). Parliamentary democracy, which dates back to about fifteen years in Hungary, has favoured the gradual strengthening of leadership in the executive in the face of the resizing of the National Assembly.

Orban, the Hungarian Prime Minister in his second term of office (from 2010, previously in 1998 until 2002), had asked the Hungarian people to vote against the quotas decided by the EU in order to relocate refugees to Europe. But the referendum held in 2016 did not reach the quorum necessary to be validated. There was therefore no plebiscite that Orban wanted to obtain, despite the populist leader claiming for himself the (useless) majority of $98 \%$ out of a total of 
voters that slightly exceeds $40 \%$ of the total and despite the widespread discontent in society towards migrants that, however, has not turned into a political choice.

There are other institutional aspects that move in the same direction: the electoral system with wide margins of disproportionality, the "vote of constructive distrust", the lack of a vote of confidence, as well as the political activism of the Government Cabinet combined with a certain consolidation of the party system and with the international political pressures aimed at shifting the balance of power in favour of the executive without risking too much the interference of the parliamentary passages [Schiemann, 2004].

After all, these are the same problems that Bernhard faced in the comparative analysis between Germany and Poland in the respective historical events of the "reconsolidation" of the democratic regime. For Bernhard, the common key to the survival and stability of the new democracies lies in the "institutional choice" whereby some systems decide to give the president elected by universal suffrage broad executive powers, while others prefer to delegate them to a president of the council; that is, some choose electoral systems that allow a large number of parties, while others establish restrictive rules in this sense. In short, the institutional choice-if you will, the very choice of one or other form of political structure-has important repercussions on the successes or failures of democracy [Bernhard, 2005].

Germany is the classic case of prolonged industrialisation in which there is a ramification of totalitarian development. The failure of the hyper-nationalist strategy of Nazism, emblematically represented by the defeat in the Second World War, which followed the failure of Weimar's democracy. With the catastrophic defeat in the Second World War, the subsequent revival of the democratic system under the control and auspices of the Western Alliance, and the European interpretation of its international mission, Germany has become one of the leading countries of globalization.

Poland, once the symbol of the failure of democratic aspirations in the states that survived the break-up of the Soviet empire, today boasts one of the most consolidated democratic systems. But here too the wind of the alliance of Visengrad (the countries of northern Europe against the continental and Mediterranean countries of the EU) blows among those countries labelled by many analysts as regimes of "illiberal democracy" [Zakaria, 2007]. In Polland too, first of all is the ideological, cultural and political program of the populist nationalist party (PiS), winner of the presidential and parliamentary elections in $2015^{1}$.

\section{USA, UK and France as a Laboratory of the New Trend}

The US president has always been the most consistent example of a leader without a party. Not that in the electoral competitions the parties do not count, on

\footnotetext{
${ }^{1}$ The approval of a law on the "rationalization" of the judicial system has provoked in 2017 many
} clashes in the country and deep disagreements with the Eu. 
the contrary they count very much for the financing and the overall organization of the electoral campaigns. But only in those. They are said to have an "intermittent" function, in the sense that they "turn on" in the pre-election phase and "turn off" in the inter-election phase, leaving almost free reign to the political leaders who contributed to their election and immediately returning afterwards to break up in their respective lobbies and associations that had formed them.

The election of Trump at the 2016 presidential elections confirms these characteristics but goes even further: it becomes one of the few cases in American political history where a candidacy for the presidency, legitimated by the victory in the "primary elections", not only was not fully supported by the candidate's party of affiliation-the Republican party-but was even often criticized and contested by the Republican exponents themselves.

Well, Trump's fortune and political successes are largely due to his own party's "orphan", becoming in effect a leader without a party: "America in front of the parties" was one of his favourite slogans. For its part, the Republican Party has faced the presidential competition of 2016 with an attitude of almost resignation and, above all, without convincing programmes or credible proposals from leaders to oppose Trump. The various Jeb Bush, last offspring of the famous presidential family, Ted Cruz, Texan ultraconservative senator, Marco Rubio, apart from the shadowy profile from the political point of view, were not able to be accredited with the Republican electorate as valid alternatives. All, however, will withdraw before the Cincinnati Convention, and all will have the opportunity to speak out against the first political initiatives of Trump, especially with regard to the so-called "Russia Connection" and the omissions on the case of the "Ku-Klux-Klan", which touch on two essential points in American conservative culture: anti-communism and anti-fascism (although referred to far from the two cases mentioned). Moreover, none of the top one hundred American newspapers have expressed endorsement in favour of Trump, and even "Atlantic" and "Usa Today", traditional megaphones of the Republican Party, have even called for a vote for Clinton in order to leave no room for a "demagogue, sexist, xenophobic, ignorant and liar" character like Donald Trump. Not to mention the critical reservations expressed by other conservative newspapers such as the Dallas Morning News, the Arizona Republic, the San Diego Union-Tribune and the Cincinnati Expirer.

On the other side of the ocean there are other events that confirm this trend. Meanwhile, at the same time as Trump's victory in the USA, the referendum on Brexit-Britain's exit from the European Union-was another significant episode in the estrangement of the electorate from the party system. Her Majesty's subjects, breaking the doubts and hesitations of the major parties, conservative and Labour, express themselves with more than half of the consensus in favour of a break with Europe, following, in fact, Nigel Farage's Ukip approach, whose electoral consent is directly (and positively) related to the European nature of the consultations (for example for the Parliament in Strasbourg and in 2016 for 
Brexit), riding this formation the widespread feelings of scepticism if not open hostility in the majority of English towards European policies (especially economic and immigration).

After the announcement of the referendum results, Cameron stood down as Prime Minister. This was despite the fact that he'd won the general election just over a year before with an increased majority. He stood down as an MP two and a half months later. Cameron's gambit paid off and in 2015 the Conservatives won an overall majority in parliament ensuring the referendum. At the time, The Independent's Matthew Norman described the referendum as an act of "indescribably selfish recklessness". The Independent's Matthew Norman described the referendum as an act of "indescribably selfish recklessness".

As prime minister, Cameron had his reservations about the influence of the European Union on Britain. Early in his political career he had opposed the introduction of the euro into British currency and had, in fact, used his opposition to the euro as a key pledge in his very first electoral campaign, in opposition to some senior party officials. Despite his scepticism, Cameron campaigned extensively with the pro-EU remain campaign, alongside politicians from both ends of the political spectrum. In brief: Cameron had serious qualms about Britain's place within the $\mathrm{EU}$ and the overbearing legislation imposed on the country. However, ultimately, he believed the country was stronger as an EU member state than an independent country [MacShawe, 2015].

But the true miracle of leadership has been made by Nick Farange to head the Ukip, interpreting the widespread resentment of the British against the EU and mobilizing the voters in the referendum in a trans-party way to vote for the exit from Europ.

But the real case from manual of democratic system to leader without party is in France with the election of Emmanuel Macron as President of the Republic in 2017 and with the election of the National Assembly, whose absolute majority is delivered by the voters to En Marche, an almost phantasmagorical party with a subliminal reference-in the name-to the national anthem of Marseille, literally "invented" by Macron and his entourage. Organisatively destroyed-registering is simple, you give your name without paying, and without other formalities: if you like the idea, you are inside-and ideologically. But also sociologically, since we do not know how many and which sectors of the French electorate voted for it.

In fact, it is a rather confused, "liquid" rassemblement [to use the words of Bauhamann], which explicitly declares, in the words of its leader, "neither right nor left". From the point of view of political geometry, it would remain the centre. But this position, within the bipartisan structure of the French system, is not so much a political place as an electoral one, obviously inhabited by moderates who, with their movements, often determine the victory of the centre-right or centre-left coalitions. And in any case, in the case of the 2017 elections, the parties traditionally placed in this area-the Gaullists and the Republicans of Fil- 
$l^{2}{ }^{2}$-express themselves explicitly in favour of an endorsement in favor of Macron. In the same way, centre-left and centre-right parties compete, especially between the first and second rounds. In the PSF, the socialist party from which Macron himself originally came [with a resumé as a technocrat and banker, he was economic consultant and then Minister of Holland], defined him as 'the man, the project of the moment'. The right wing is covered by Bayrou'sMoDem, heir of the "Unionists". The far left of Mélenchon ${ }^{4}$ and the far right of Marin Le Pen, who is the losing challenger to the presidential elections, remain outside the chorus of approva.

\section{Italy's Version}

The model of democracy at leaders-without-party offers interesting feedback also in the recent Italian political history. The Italian case provides an important confirmation to the entire process of transformation of democracy we are talking about.

The strengthening of executive power outside the traditional patterns of parliamentarianism, the crisis of de-legitimization of the party system, show the most evident outline of "chancellor democracy". The accentuated personalization of political leadership and the growth of populist sentiments in the civic culture and through all the social groups, as is clear after the 2018 elections, integrate the series of elements that mark the model of drift of representative democracy, as we have seen comparatively succeeding in many others countries of the Western World.

In 1994 he began to play the role of Berlusconi that the party-Forza Italia-invented from scratch, like Macron, as an electoral committee. It was then Monti's turn, after the experience of technocratic government at the end of the millennium, that constituted an electoral list, "SceltaCivica", to guarantee himself and his few supporters a minimum of political survival. Therefore, we have the experience of the Renzi government, the most consistent with the logic of partylessleaderism. Indeed, the party is there and it is the PD. However, it cannot be said to be united around his leader, who for his part prefers to lean on a small group of trusted friends (someone maliciously gives him the name of "Magic Lily" [Huffington Post, August 4, 2015] and on "variable geometry" majorities for legislative activity. So as not to leave out Grillo and his "five-star" movement, whose fortunes are linked to the failure of traditional politics, to the ${ }^{2} \mathrm{He}$ says: "We are not even centrist, we are central".

${ }^{3}$ In his recent book, Résolutionfrançaise, Francois Bayrou (2017) makes a speech that takes up that of his new ally: "Left and right are groups that are now empty, or at least largely exhausted".

${ }^{4}$ Which speaks of a "majority without legitimacy", also referring to participation rates, actually not much below the average in France [Melenchon, 2017].

5"The technocrats say that there are rational solutions to political problems, whether the people like it or not. Populism, which rejects the primacy of the so-called experts, offers an equal and opposite alternative. Tecnocracy and populism have in common the rejection of mediation, and therefore of representative democracy. Just as democracy serves the people, populism serves the elite" [Muller, 2001]. 
crisis of representativeness of political parties, to the populist and/or technocratic drift of the civic culture of the country, since populism and technocracy can be considered two sides of the same "qualunquista" (politically apathetic) medal that often favours and distinguishes the transition to democracy with leaders-without-party ${ }^{4}$.

Indeed, in the case of the Five Star Movement and its leader Beppe Grillo, it would be more appropriate to speak of anti-leaders: like those who act through social mobilization, promoted digitally but made in the streets and amplified by the media-like the "V-Days". But Renzi, the "scraper", is also an anti-leader, who has built his own affirmation on the demolition and integral replacement of the traditional political class. And, coherently, it has conquered the leadership of the PD with the legitimization of the mass rite of the primaries. He did not create a "personal party". But it has over-customised the Democratic Party. He gave it his own image. On the contrary, it imposed and overlapped it. Because the PD, for history and organization, is not able to coagulate around "a" leader. The PD, thus, became the PDR. The Democratic Party of Renzi. That exploits and sums up the rooting of the PD and the personal attraction of the leader. This explains the unexpected success at the European elections. In the name of the removal of the old ruling class. Renzi, however, affirmed a hyper-personalized model of leadership (and democracy) [Diamanti, 2014].

It is not just a coincidence that, after Macron's victory, the race for eulogy and emulation began. Monti speaks of "a considerable convergence of views"; Renzi, with more emphasis twist: "now we march ahead too" and fairy tale of a NPC (party of the nation) neither left, nor right, adopting the slogan of En Marche.

\section{Hibrid, Dissociative or Personal Party Democracy}

A "hybrid democracy", defines Diamanti as the regime recognizable in the Italian political system which, after the elections of 2013, assumed new forms of representation [Ibidem]. As is described in the idealistic models of comparative politics, it is a regime poised between liberal-democracy and authoritarianism [ibidem]. The new model, which came to the fore at the end of the 90 's, has as its next cause widespread abstention, in turn caused by the crisis of legitimacy of the institutions and of the party system. The citizens-electors from protagonists have become spectators, unlike the democracy of the parties of "first republic" and the democracy of the public of "second republic".

This situation of crisis has been also presented in the terms and substance of a "dissociative democracy", in a sense literally opposed to Lijphart's idea of a "consensual democracy" [Lijphart, 2001]. The dissociation that is highlighted here is that of a society (in Italy) in which the "fractures", identified by Lijphart in the face of a political system that tends to counterbalance these conflicting "V-day" stands for the day of "fuck you", the vulgar insult turned against politicians, political parties and estabilishment, the watchword with which the movement, until then only mediatic, materializes for the first time in tens of thousands of people mobilized in the streets of Bologna in the autumn of 2007. 
pressures with large and sometimes unthinkable coalitions of government, do not persist, but a society where lines are developed, even if weak, of solidarity against political elites and parties in perennial conflict, almost at war with each other for the conquest of power for power, having lost any reference to the social base of representation [De Mucci, 2013].

Both analyses converge, however, in defining what is looming, in the run-up to the 2013 elections, as an electoral democracy, personal, mediatized, which brings together different manifestations of pathology. Among the most conspicuous (and worrying), the transformation of the parties that have preferred television and media communication to active participation and organization on the territory, as well as the leadership and personalization of the management, using consultants and marketing professionals. Think of the birth of the "five-star movement": born on the net, it immediately affirmed Grillo as a leader disguised as "anti-leader", while populism has become a style of political language and communication.

Diamanti writes about it:

"Media populism. This orientation is fuelled by the way in which media policy and government are dealt with. In programmes where priority is given to the themes of daily life, which listen to and make popular men, places and topics of politics. So the boundaries between entertainment and deepening almost disappear. Everything mixes and hybrids... journalists, actors, soubrettes, cooks, experts of all kinds: together with politicians they participate in pop politics. Where to become and remain popular, political leaders must adopt a populist style and language. On the other hand, ideologies are no longer taken into account and are replaced by narratives. Storytelling" [Diamanti, 2014: p. 29-30].

Mauro Calise also believes that, with the advent of the digital network and cultures, public opinion is "put in a corner". To leave room for who and what, it is, however, still difficult to say. For Calise, Italy remains, even today, an anomalous case in the Western panorama, since the absence of an "authoritative and consolidated monocratic institutional role to which to anchor the trend of personalization" has generated a full identification between person and party-the "personal party" - which does not seem at all destined to decline and, above all, to be supplanted by organizational forms capable of reactivating participatory and democratic circuits [Calise, 2013].

"Modern leaders are not on course for democracy; on the contrary, in many ways, they embody its extreme development. They enjoy broad popular support, in increasingly plebiscite and sondocratic forms that cannot, however, be accused of violating the basic principle of democracy: the investiture by a majority of voters. Their strength lies precisely in being able to boast of having restored-often through the instrument of direct election-the relationship between leaders and people that the old parties had worn out. Moreover, the concentration of command in a single man is taking place today, while state institutions appear increasingly incapable of fulfilling their historical role as a con- 
tainer and reference for the associated life. The first body of the king regains the upper hand also because the second body appears in disintegration" [Calise, 2016: p. 39].

The new leaders come to power with two key elements of post-modernity. First of all, the ability to reflect, and interpret, that centrality of the individual which is the emerging cultural trait at the turn of the century. Anticipated by the Thatcherian and Reaganian revolutions, declined in the obvious ideology of neoliberalism, the narcissistic explosion of the ego is the social platform that relaunches personal power as a model of leadership. By joining and multiplying with the second factor that distorts the institutional building: the triumph of entertainment politics, which turns its spotlight on large-and small-personalities. Contained at the beginning by the systems of self-protection and self-censorship of the old parties, the invasion of television overturns in a few years the formats of the national networks. From the incipitated and marshy television stands of the beginnings we pass to the stands of the people in direct and uncontrolled grip with their audience. Instead of politicians without a body, the exhibition of the media body of leaders, the new icon of mass communication, triumphs.

Unlike Forza Italia, the PD of Renzi is definitely not a personal party [Calise, 2010; McDonnell, 2013]. It is not a party-company, of a "proprietary" nature: a party that begins and ends with its leader, as it is inseparably linked to the financial and organizational (private) resources of the founder. On the contrary, it is a party that "pre-exists" the leader. And (probably) he will survive the leader. A party with a solid organization, an articulated territorial structure, and "rules" that govern internal life. They shall limit the room for manoeuvre of the Secretary in terms of his or her prerogatives and term of office. It is, however, a highly personalised party. At least in the process of rapid customization, due to the effect of the change impressed by the new leader [Bordignon, 2014: p. 439].

\section{Conclusion-Another Kind of Leadership: At the Thresholds of Populism?}

There is no doubt that in recent years there has been a growing personalisation which is profoundly transforming, as well as the structures of parliamentary democracy, the very model of liberal democracy based on the principle of representation. In truth, nothing is new in the history of Western political systems. In some ways one could speak of a progressive realization of what Max Weber had foreseen-but above all hoped for-in the last century at the dawn of the Weimar Republic. But the crucial role that the media-and in particular television-have assumed in this process in modernity seems, however, to call into question two essential aspects of his hypotheses. The first concerns the risks-seen by the German sociologist-that even through the media, deteriorating forms of personalization linked to the mobilization of the "emotional elements" of the masses can now find more space; a danger increased by the weakening of the organized parties that-contrary to what is often thought con- 
sidering above all the aforementioned papers-Weber did not see with favour. For him, effective personalisation should not have been a mere opposition to parties. The second aspect, always linked to the media, concerns the growing possibilities that these instruments offer of autonomy from the parties, but at the same time of greater dependence on particular interests mobilized by the leading candidates to finance the increasingly costly electoral campaigns [Weber, 1982: p. 178].

The combination of these two trends puts at risk an adequate selection of political figures with high moral qualities, competence and dedication to the cause of general interests. The essential precondition on which Weber based the innovation expectations of political leaders in support of the general interests of the nation-state thus becomes more fragile [Weber, 1971: p. 99]. But Weber's strong link between personalization and the consequences of political action is also questioned from the point of view of the expected benefits of greater decision-making capacity and speed. We have seen how customisation is more present in majority democracies than in consensual ones, but it does not go hand in hand with clearly distinctive results in terms of better socio-economic performance in majority contexts. Rather, as we have seen, if we were to interpret the benefits of the leadership that Weber wanted as the ability to support market capitalism with strong cohesion and social integration that would strengthen the nation-state, it is consensual democracies, especially those of continental Europe, that are the closest to this goal. However, the reasons why personalisation is more widespread in majority contexts but does not bring the benefits in terms of public action that are often attributed to it still need to be examined in depth from a theoretical point of view. It is not possible to address the problem here, but we can, in conclusion, put forward a number of hypotheses. First of all, in a context characterised by majority electoral rules and competition between two parties-in which "winners take everything"-we need greater cultural cohesion, a more homogenous political culture that mitigates the risks of change for those who are defeated, hence the narrowest ideological and programmatic differences between the parties. But from here also the more favourable conditions for the personalization of leadership are: the less the programmatic differences are, the more space it is necessary to give to the personal characters of the candidates to distinguish themselves and seek more consensus. In addition to this factor, one can also consider that in a situation where only two parties are protagonists, the drive to win an electorate that is placed at the center of the political spectrum, and is decisive for the electoral victory, requires the combination of different interests and not easily reconcilable.

The personalization of the leadership, shifting the focus on the candidate's characters-his competence, his reliability, his image-allows to maintain a more uncertain and ambiguous programmatic offer without penalizing the party in the competition. It also gives the leader more power than the leadership and the members of his party and allows him to make difficult choices [Colin, 2007]. 
For example, in the case of a centre-left party, to make choices that guarantee the consent of the moderate electorate even at the expense of its own base of reference in the less privileged groups. As a consequence, however, it is likely that abstention or populism will increase among these very groups [Iversen \& Soskice, 2006; Hay 2007]. This leads us to the problem of the consequences. Personal leadership of the moderate electorate, on whose consent electoral victory depends, will be less inclined to engage in effective redistributive or regulatory action that penalises the middle electorate in terms of taxation or other constraints. This trend is combined with a generally more liberal political culture, in favour of de-regulation and a more limited welfare. Industrial relations and the role of trade unions are not encouraged, and representation of interests remains pluralist. On the other hand, the greater instability of the personal leadership directs the political action in the shorter term, in search of immediate consensus, and this does not favour more complex interventions but of greater strategic impact, which have a longer yield and require the consultation with the representative organizations of interest. Hence the outcome in terms of a more liberal capitalism with strong and growing social inequalities. In short, on the one hand Weber's expectations of a growth in personalization seem to be confirmed, but on the other hand the effects in terms of economic and social performance that the German sociologist associated with consensus based on the personal qualities of leaders and the greater concentration of power in their hands are not clearly distinguishable. Rather, one can see signs of a growing consumption of personal leadership, which is spreading, is increasingly sought after as a miracle drug but at the same time becomes lower quality, more unstable, and limited in its possibilities of action in favour of a market economy that is also socially cohesive. Can we then speak of a personalisation of leadership that increases speed and capacity for choice, but with greater difficulty in effectively combining growth and social cohesion? I believe that this question is legitimate and that it should be placed at the centre of the agenda today, not least through greater integration between sociology, political science and the political economy.

\section{Conflicts of Interest}

The authors declare no conflicts of interest regarding the publication of this paper.

\section{References}

Bayrou, F. (2017). Resolution francaise. Paris: Edition de l'Observatoire.

Bernhard, M. (2005). Institutions and the Fate of Democracy: Germany and Polland in the Twentieth. Pitsburg: Pittsburg University Press. https://doi.org/10.2307/j.ctt5hjrk1

Bordignon, F. (2014). Dopo Silvio, Matteo: Un nuovo ciclo personale? La democrazia italiana tra berlusconismo e renzismo. In Comunicazione politica, Rivisteweb Il Mulino, Fascicolo 3.

Calise, M. (2010). Il partito personale. I due corpi del leader, Roma-Bari: Laterza. 
Calise, M. (2013). Fuorigioco. La sinistra contro i suoi leader. Roma-Bari: Laterza.

Calise, M. (2016). La democrazia del leader. Roma-Bari: Laterza.

Colin, H. (2007). Why We Hate Politics. New York: Wiley Publ.

De Mucci, R. (2013). Democrazia dissociativa. Soveria-Mannelli: Rubbettino.

Diamanti, I. (2014). Democrazia ibrida. Roma-Bari: Laterza.

Diamanti, I. (2014). Oltre la democrazia del pubblico. In Comunicazione politica, Rivisteweb Il Mulino, n. 3.

Fabbrini, S. (1991). Il governo del leader-con-partito. Rivista Italiana di Scienza Politica, 3, 161-196.

Helms, L. (2011). Angela Merkel and the Unfilled Promise of Chancellor Democracy. Current History, 110, 97-102.

Iversen, T., \& Soskice, D. (2006). Electoral Institutions and the Politics of Coalitions: Why Some Democracies Redistribute More than Others. The American Political Science Review, 100, 165-181. https://doi.org/10.1017/S0003055406062083

Lijphart, A. (2001). Le democrazie contemporanee. Bologna: Il Mulino.

MacShawe, D. (2015). How Britain Will Leave Europe. London: I.B. Tauris Publisher.

Melenchon, J. L. (2017). Francia, Macron Assolutamente. Vancouver: Pressreader.

Mommsen, H. (2007). The Origins of Chancellor Democracy and the Tranformation of the German Democratic Paradigm. German Politics and Society, 25, 7-18.

Morlino, L. (2010). Legitimacy and the Quality of Democracy. International Social Sciences Journal, 60, 211-222. https://doi.org/10.1111/j.1468-2451.2010.01717.x

Muller, J. W. (2001). Cos'è il populismo. Milano: Ube.

Schiemann, J. W. (2004). Hungary, the Emergence of Chancellor Democracy. The Journal of Legislative Studies, 10, 128-141. https://doi.org/10.1080/1357233042000322265

Tulis, J. K. (1987). The Rhetorical Presidency. Princeton, NJ: Princeton University Press.

Weber, M. (1971). La politica come professione, in Il lavoro intellettuale come professione. Torino: Due saggi, Einaudi.

Weber, M. (1982). Parlamento e governo nel nuovo ordinamento della Germania, in Parlamento e Governo e altri scritti politici. Torino: Einaudi.

Zakaria, F. (2007). The Future of Freedom: Illiberal Democracy at Home and Abroad. New York, NY: W.W. Norton \& Company. 